\title{
1. At Brexit crossroads: autonomy and gains from trade as alternatives? Introduction and overview ${ }^{1}$
}

Hans-Bernd Schäfer and Jörn Axel Kämmerer

\section{WHY BREXIT? THE SOURCES OF EURO-SCEPTICISM IN THE UK}

'Brexit means Brexit.' Theresa May's famous political statement has often been cited, but mainly for its ambiguity and vagueness. She was clear only about the intention to end membership in the EU and its organs. She left open whether future relations between the EU and the UK should follow the Norwegian or the Swiss model, or the free trade agreements concluded with Japan, South Korea, Canada or Ukraine, or be subject to WTO rules only, in which case the withdrawal would be dubbed a hard Brexit. We may assume that the vagueness of Theresa May's slogan was not unintended and that it served as a disguise (though a semi-transparent one) of the dissenting views in the UK on whether and how the Kingdom should leave the single market views that ranged from a close economic partnership via a loose free trade zone to no special economic ties at all.

Most UK governments have viewed the idea of an ever-closer union (as enshrined in the Preamble of the TFEU) with scepticism. ${ }^{2}$ In 2016, just ahead of the Brexit referendum, then Prime Minister David Cameron even wrested from the EU the promise that his country would not have to join the other EU members on that path. ${ }^{3}$ That British scepticism is evidenced by the special pro-

\footnotetext{
For valuable information and comments on an earlier draft we thank Peter Behrens, Rolf Langhammer, Hein Kötz, Ejan Mackaay, Claus Ott and Mehrdad Payandeh. The usual disclaimer applies.

2 'British Euroscepticism: a brief history', The Guardian Online of 7 February 2016, available at www.theguardian.com/politics/2016/feb/07/british-euroscepticism-a -brief-history, last accessed 28 September 2020.

3 The UK Government and the EU agreed on a 'New settlement for the UK within the European Union': see General Secretariat of the Council, 'European
} 
visions in Protocol Nos 15, 20, 21 and 30 to the founding Treaties (a price paid to the UK for its approval of the Maastricht Treaty). The UK has abstained from the Economic and Monetary Union (which according to Protocol No. 15 it was free to join if and whenever it so wished) and the Schengen system, and has also made substantial use of its 'opting out' prerogative regarding the 'Area of freedom, security and justice'. ${ }^{4}$ Politically, the UK has opposed, alongside several allies, the harmonisation of taxes and tax avoidance rules, and while it does not generally advocate deregulation of financial markets supervision it has opposed some stricter rules, such as legal instruments for the (temporary) prohibition of short sales, ${ }^{5}$ which it (unsuccessfully) attempted to block before the European Court of Justice. ${ }^{6}$ Since 1992, Europe has been advancing unevenly and at different speeds. Long before Brexit, the UK more than any other Member State insisted on a slower speed. It might have continued stalling its own integration for some more time, formally remaining a member of the Union, criticised by others for its 'cherry-picking'7 - a member of the team, but a benchwarmer rather than a pacemaker. However, considering the increasing

Council meeting (18 and 19 February 2016) - Conclusions', EUCO 1/16, available at www.consilium.europa.eu/media/21787/0216-euco-conclusions.pdf, last accessed 23 September 2020; Prime Minister David Cameron presented this agreement to the British parliament as 'the best of both worlds': see UK Government, 'The best of both worlds: the United Kingdom's special status in a reformed European Union', February 2016, available at https://assets.publishing.service.gov.uk/government/uploads/system/ uploads/attachment_data/file/502291/54284_EU_Series_No1_Web_Accessible.pdf, last accessed 23 September 2020.

4 For an overview of opt-out decisions taken between 1 December 2009 and 2017, see Ministry of Justice, 'Decisions taken: JHA (Title V) opt-in and Schengen opt-out decisions', available at https://assets.publishing.service.gov.uk/government/ uploads/system/uploads/attachment_data/file/695125/Opt-in_webpage_update_-_data - ${ }_{-}^{-}$March 2018.pdf, last accessed $2 \overline{3}$ September 2020.

5 In this, the UK was proven right by the 'Wirecard affair' that came to full light at the beginning of 2020: had no temporary prohibition to short-sell Wirecard shares been imposed by the German Federal Agency for Financial Market Supervision between 18 February 2019 and 18 April 2019, many investors would probably have been deterred from investing in a fraudulent company and the criminal activities of its board members would have come to light earlier. 2014:18.

6 European Court of Justice, Judgment of 22 January 2014, C-270/12, ECLI:EU:C:

7 As done, for example, by former Foreign Minister of Germany Guido Westerwelle, reacting to proposals by Prime Minister David Cameron on the British role in a reformed European Union: 'Reaction to Cameron's EU speech: "A politics of cherry-picking will not work", The Guardian Online of 23 January 2013, available at www.theguardian.com/politics/2013/jan/23/david-cameron-europe-international -reaction, last accessed 23 September 2020; Kämmerer, Europeanisation of Financial Markets Regulation in Times of Brexit, European Company and Financial Law Review 2017, p.641. 
alienation of the UK from most of its partners in the EU, the question whether a continuation of full British membership in the EU made sense would have appeared on the agenda sooner or later, even if the UK had not decided to withdraw.

Given that the decision was made and implemented, all speculation on how things might have otherwise evolved shall end here and our analysis shall instead dwell on what triggered the withdrawal. An important reason for the naysayers' majority in the Brexit referendum was widespread British dissatisfaction with the free flow of labour within the EU. That hallmark of the EU and its internal market (Art. 26 TFEU) had become a political burden after eight formerly communist countries joined the EU. Migration figures from these new Member States, especially from Poland, far exceeded expectations. Despite positive overall economic effects, this was perceived as burdening the social welfare system, including the National Health Service, and it dampened the wages of low-skilled British workers. ${ }^{8}$ The British government unsuccessfully looked for a possibility to curb the influx of workers from the new Member States. Simultaneously, refugees from outside Europe were entering the EU - which failed to agree on a common strategy on the matter - with many also reaching the UK. These two migration phenomena strongly contributed to triggering the - scant - majority of British votes in favour of leaving the EU.

In addition, all this happened against the backdrop of the global financial crisis of 2007/8, which provoked fiscal crises in Greece, Cyprus, Ireland, Italy, Portugal, Spain and other countries, threatening the stability of large commercial European banks in other Eurozone countries and eventually the existence of the euro itself in 2012. It contributed to euro-scepticism in the Eurozone itself and was grist to the British Europhobes' mills. The crisis management - a combination of loans provided by the Union and its Member States, alongside austerity policy - fuelled populism and political instability and consolidated the dubious image of the EU as a stagnating and unstable economic zone that was no longer a worthy partner for the UK. Hard Brexiteers developed the idea of a 'Global Britain' to align with other, economically more vigorous partners around the world. ' This 'Global Britain' would have shed the bonds that other economically strong actors, such as Germany, firmly integrated in the EU, would never have been able (or willing) to untie. An autonomous

8 Nickell/Saleheen, The Impact of Immigration on Occupational Wages: Evidence from Britain, Bank of England, 2015, Staff Working Paper No. 574, pp.1-44.

9 Under this 'brand' activists have issued research and policy papers on reasons to leave the EU, see e.g. 'The true cost of EU membership', The Brexit Papers, Global Britain, 2017, available at https:/globalbritain.co.uk/wp-content/uploads/2017/11/ The-Brexit-Papers-8-The-true-cost-of-EU-Membership-FINAL.pdf, last accessed 23 September 2020. 
foreign trade policy would allow the British government to make its own best choice of trade agreements in foreign relations with the EU or other partners, to shape new rules with other international trading partners and to move away from a stagnating Europe to fast-growing markets farther afield.

The powerful position of the European Court of Justice as a motor of integration further fuelled the scepticism of hard Brexiteers. Even though the Court's role had no major place in the referendum campaign, it gained in prominence in the subsequent debates under the slogan 'taking back control'. The withdrawal agreement signed by the parties on 24 January $2020^{10}$ - an in-depth analysis of which is presented in this volume by Jörg Philipp Terhechte - still grants a major role to the ECJ in dispute resolution, but only until the end of 2020, when the period of transition is supposed to end, with no extension in sight at the time of writing. According to this agreement, the competent dispute resolution panel must refer to the Court of Justice of the EU if a decision depends on EU law and its authoritative interpretation. ${ }^{11}$ In the proposals submitted by the British government in February 2020, it firmly and explicitly opposed any role of the ECJ in the future relations between the EU and the UK, and it considers this issue a red line. ${ }^{12}$

Finally - and this observation partly contrasts with the aforementioned aspirations for a 'Global Britain' - hard Brexit has gained support from nationalist and populist thinking and a rather nostalgic desire for the good and glorious old times. There seems to be little scholarly analysis of this backward-oriented thinking and its political effects, but it certainly is a highly relevant political

10 Agreement on the withdrawal of the United Kingdom of Great Britain and Northern Ireland from the European Union and the European Atomic Energy Community of 12 November 2019, OJ C 384I, pp.1-177.

11 Agreement on the withdrawal of the United Kingdom of Great Britain and Northern Ireland from the European Union and the European Atomic Energy Community of 12 November 2019, whose Art. 174 reads: 'Where a dispute submitted to arbitration in accordance with this Title raises a question of interpretation of a concept of Union law, a question of interpretation of a provision of Union law referred to in this Agreement or a question of whether the United Kingdom has complied with its obligations under Article 89(2), the arbitration panel shall not decide on any such question. In such case, it shall request the Court of Justice of the European Union to give a ruling on the question. The Court of Justice of the European Union shall have jurisdiction to give such a ruling which shall be binding on the arbitration panel.'

12 HM Government, 'The Future Relationship with the EU - the UK's Approach to Negotiations', February 2020, available at https://assets.publishing.service.gov .uk/government/uploads/system/uploads/attachment_data/file/868874/The_Future _Relationship_with_the_EU.pdf, last accessed on 23 September 2020: 'The arrangements will reflect the regulatory and judicial autonomy of the UK and accordingly there will be no role for the Court of Justice of the European Union in the dispute resolution mechanism.' 
factor, not only in England but in many countries around the world. Nationalist thinking, as cherished by some Brexiteers, has become something like an antithesis to the very process of economic internationalisation and globalisation cherished by those Brexiteers who aspire to a 'global Britain'. In this volume, Ejan Mackaay gives an insight into the populist underpinnings of Brexit.

This opening chapter reviews in some more detail the above factors and the scholarly perspectives on them, as well as their potential legal and economic consequences, many of which are subsequently analysed in more detail by the authors of this volume. We conclude with an outlook on future economic relations. We believe that after Brexit, Britain is unlikely to sail out of sight of the EU. Irrespective of their continued geographical proximity, the EU and the UK could both expect substantial economic gains from an agreement with even relatively modest concessions. Even if, by the end of 2020, the negotiations yield but the most meagre of results - if any - that will not be the last word. The gravitational force of geography will make Brexit the beginning of a long period of private initiatives and public negotiations for new forms of cooperation.

\section{2. 'GLOBAL BRITAIN': RECIPE FOR A PROMISING FUTURE OR FOR FAILURE?}

As already mentioned, a 'Global Britain' involves sovereignty and autonomy of the UK government and parliament in negotiating, and assenting to, free trade agreements with other countries. Its advocates count on new opportunities to strengthen economic ties with non-EU partners, especially China, the USA and Commonwealth countries. This economic vision is incompatible with a customs union (where Member States cannot negotiate their own customs tariffs), let alone a single market involving both the EU and the UK. The same is true of something akin to the European Economic Area (EEA), which governs the EU's relations with Norway, Iceland and Liechtenstein. ${ }^{13}$ Although the EEA is not a customs union, the freedoms of the single market apply to it, including, in principle, the free movement of workers and the freedom to provide services, which is equally enjoyed by banks and by the

13 Schroeter and Nemeczek even argue that the UK remains part of the EEA after Brexit: 'Brexit', aber 'rEEAmain'? Die Auswirkungen des EU-Austritts auf die EWR-Mitgliedschaft des Vereinigten Königreichs ['Brexit', but 'rEEmain'? Implications of an EU withdrawal for UK's EEA membership], Juristenzeitung, 2017, pp.713 et seq.; for a contrary viewpoint see Told, (BR)EXIT from the EU - A Legal Perspective, European Company and Financial Law Review, 2017, pp.518 et seq. 
Polish plumber. ${ }^{14}$ 'Trade in services' with third countries is a more intricate matter than trade in goods, as Friedemann Kainer points out in his article, because the former often necessitates the free movement of persons or at least an arrangement between States on qualification requirements.

EFTA members of the EEA are expected to transpose the relevant secondary EU legislation into national law (for which a special endorsement procedure has been established); ${ }^{15}$ their sovereign right to reject it exists only on paper. Full British sovereignty in trade matters would also stand in the way of emulating the various agreements concluded between the EU and Switzerland, ${ }^{16}$ which provide for an 'autonomous re-enactment' of EU law by Switzerland - but not for 'passporting' in the provision of financial services, that is, unrestrained access to the financial markets of all Member States. ${ }^{17}$ No one should expect the EU to make more concessions to the UK than to Switzerland, which is just as much of a powerhouse in international banking as the UK, while being willing to maintain much stronger ties with the Union.

\subsection{The Gravity Model of International Trade as an Analytical Tool}

Economists have found that much of the trade between any two States can be explained by the gravity model, which has also played a prominent role in evaluating the potential effects of Brexit. The following formula describes quite accurately the volume of trade (exports plus imports) between country 1 and country 2 .

$$
V_{1,2}=\frac{a \cdot Y_{1} \cdot Y_{2}}{D_{1,2}}
$$

$V_{1,2}$ is the volume of trade between the two countries, $a$ is a parameter to be estimated with econometric methods from the available empirical data, $Y_{i}$ is

14 On the nature of the EEA and its relation to the EU see Kinander, The Norwegian Model for Access to the European Financial Markets: The Principles and Practicalities of the EEA States' Solution to the Passporting Issue in Light of Brexit, European Company and Financial Law Review, 2018, pp.236 et seq.

15 Art. 7 of the Agreement on the European Economic Area in conjunction with Protocol No. 35; see on this Dystland/Finstad/Sørebø, in Arnesen/Fredriksen/Graver/ Mestad/Vedder, EEA Commentary, 1st edition 2018, Art. 7, rec. 1 et seq.

16 Swiss Federal Department of Foreign Affairs, The Main Bilateral Agreements and Arrangements between Switzerland and the EU, September 2016, available at www .eda.admin.ch/dea/en/home/bilaterale-abkommen.html, last accessed 23 September 2020.

17 Armour, Brexit and Financial Services, Oxford Review of Economic Policy, 2017, pp.S54-S69. 
the Gross Domestic Product (GDP) of each country and $D_{1,2}$ is the distance between the countries. ${ }^{18}$ Thus, a large share of the trade volume between two countries is explained by their GDP (positive relationship) and geographical distance (negative). ${ }^{19}$ This is - in analogy to Newton's theory - the gravity model of international trade. Of course, other variables, such as common language, climate, endowment with mineral resources, economic policy and international trade law, also play a role. Yet geographical proximity explains why there is more trade between the EU and the UK than, for instance, between the UK and the USA (although the latter volume is admittedly larger than the gravity model would predict, whereas the model quite accurately predicts the trade volume between the USA and Germany). Many empirical studies underpin that an increase in distance significantly reduces the volume of trade. This observation stands in sharp contrast to the general public perception about modern international trade. The bestselling books The Death of Distance by Frances Cairncross $(1997)^{20}$ and The World Is Flat by New York Times journalist Thomas Friedman $(2005)^{21}$ are telling examples of the popularity of that view, which is now also shared by some prominent Brexiteers, including Liam Fox, the former British minister of international trade, who ran for the WTO Presidency: 'My department will have the freedom to negotiate, sign and ratify new trade agreements. [...] We can begin to build closer commercial relationships with our closest allies, such as the US, New Zealand and Australia, as well as laying the groundwork for improved market access for UK companies to key global growth economies.' ${ }^{22}$ But these remote countries, some of which are moreover comparatively small, cannot easily replace the EU as a trading and business partner. The proponents of that view also neglect that various 'global growth economies' are members of the EU - Eastern European countries that have been experiencing strong growth after the collapse of communism. Gravity will prevail and will ultimately pull Britain (when some of its dreams will have turned out to be delusions) towards the negotiating table, because small British concessions to the EU would yield much bigger economic advantages than the same concessions made to faraway countries.

18 Krugman/Obstfeld, International Economics, Theory and Policy, 11th edition, 2017, p.15.

19 Carrère/Mrázová/Neary, Gravity Without Apology: The Science of Elasticities, Distance and Trade, The Economic Journal, 2020, pp.880-910.

20 Cairncross, The Death of Distance, 1998.

21 Friedman, The World Is Flat, 2007.

22 Liam Fox, Speech, 30 November 2018, available at www.gov.uk/government/ speeches/speech-a-world-beyond-europe-a-time-beyond-brexit, last accessed 23 September 2020. 
What are the findings of economists who rely on facts and theory, rather than on wishful thinking about a flat earth? Carrère et al., ${ }^{23}$ having reviewed the literature, present their own research on Brexit's impact on the British economy in the shape of 'the three iron laws of Brexit'. First, Brexit comes at a net cost to the British economy under all possible scenarios. Second, the harder the Brexit, the higher will be its cost in terms of lost GDP. Third, even the hardest imaginable no-deal Brexit will not cause enormous costs for the British economy.

The predictions on the macroeconomic effects of Brexit made in various available studies conducted by academic scholars are fairly unanimous. ${ }^{24}$ Based on gravity models, it has been estimated that UK GDP would incur a one-time drop of 2 per cent in case of a negotiated Brexit without trade barriers between Britain and the EU, and that GDP would nosedive by 6-7 per cent as a result of a hard Brexit. These losses are significant and dramatic but not catastrophic. What the analyses could not foresee, however, is that the UK's economy would have to grapple with a second and coinciding crisis - Covid-19 - and could therefore suffer a much more serious downturn than in the case of Brexit alone. The share in that downturn that could be attributable to the latter would probably not exceed Britain's losses in the wake of the financial crisis in 2007/8. Still, the authors highlight that being willing and prepared to accept losses of such a scale (and we must assume that some Brexiteers know these predictions and take them seriously) is something unprecedented in British peacetime politics. Joint research by the French, Spanish and German Reserve Banks found UK GDP would incur one-time losses of 3-7 per cent both in a soft and a hard Brexit. The authors also forecast losses for the EU, but much more modest ones in relative terms - below 0.5 per cent of the EU's GDP in both scenarios. ${ }^{25}$ It is an illusion to believe that in the event of a hard Brexit,

${ }^{23}$ Carrère/Mrázová/Neary, Gravity without Apology: The Science of Elasticities, Distance, and Trade, p.880.

24 Brakman/Garretsen/Kohl, Consequences of Brexit and Options for a 'Global Britain', Papers in Regional Science, 2018, pp.55-72; Dhingra/Huang/Ottaviano/ Pessoa/Sampson/Van Reenen, The Costs and Benefits of Leaving the EU: Trade Effects, Economic Policy, 2017, pp.651-705; Mayer/Vicard/Zignago, The Cost of Non-Europe, Revisited, Economic Policy, 2019, pp.145-99; Sampson, Brexit: The Economics of International Disintegration, Journal of Economic Perspectives, 2017, pp.163-84.

25 Berthou/Haincourt/de la Serve/Estrada/Roth/Kadow, Assessing the Macro economic Impact of Brexit through Trade and Migration Channels, Banco de España Ocassional Paper No. 1911, 2020, available at https://papers.ssrn.com/sol3/papers .cfm?abstract_id=3523738\&download=yes, last accessed 23 September 2020. For 
where only the WTO rules would continue to apply, the lost trade between the UK and the EU could easily and completely be compensated for by intensified trade with distant countries. This illusion, however, is nourished under the 'Global Britain' banner. Brakman et al. summarise their empirical study as follows:

We confirm Brexit's substantial, negative trade effects for the UK, EU, and major countries around the world. After reviewing all potential options, our answer to the question whether the UK has an alternative for the existing agreement with the EU is: No. Paradoxically, only a trade agreement with the EU can compensate for Brexit's trade losses ${ }^{26}$

\subsection{Is the European Union a Zone of Economic Stagnation?}

Apart from geographical distance, any country's foreign trade with another country depends on, and increases strongly with, the size of the domestic and the partner's economy. Eurosceptics regard the EU as an economically stagnating zone - still relatively wealthy but on the brink of falling apart. According to the Brexiteers, the UK must not be caught up in that maelstrom of economic downturn and should instead reclaim control over foreign trade by turning toward new and more dynamic partners. This view is not corroborated by facts, either.

Presently, the EU is the second largest economy in the world - behind the USA, and still ahead of China. Together with Japan and India, these five powers account for two thirds of global economic output. Between the Napoleonic era (when somewhat reliable data was first collected) and the 1980s, growth rates in high-income countries had surpassed those of middle and low-income countries, with only a handful of noteworthy exceptions in East Asia. Then China, India and numerous other low and middle-income countries moved from central planning to market economy and from import substitution to globalisation, and succeeded in protecting private investors either by law or substitute institutions. ${ }^{27}$ Ever since, economic growth in these

other empirical studies on the economic impact of Brexit, see Davies/Studnicka, The Heterogeneous Impact of Brexit: Early Indications from the FTSE, European Economic Review, 2018, pp. 1-17; McGrattan/Waddle, The Impact of Brexit on Foreign Investment and Production, Federal Reserve Bank of Minneapolis, 2018, Research Department Staff Report 542; Sampson, Brexit: The Economics of International Disintegration, Journal of Economic Perspectives, 2017, pp.163-84.

$26 \mathrm{Brakman} /$ Garretsen/Kohl, Consequences of Brexit and Options for a 'Global Britain', Papers in Regional Science, 2018, pp.55-72.

27 Cooter /Schäfer, Solomon's Knot: How Law Can End the Poverty of Nations, 2012, p. 15 . 


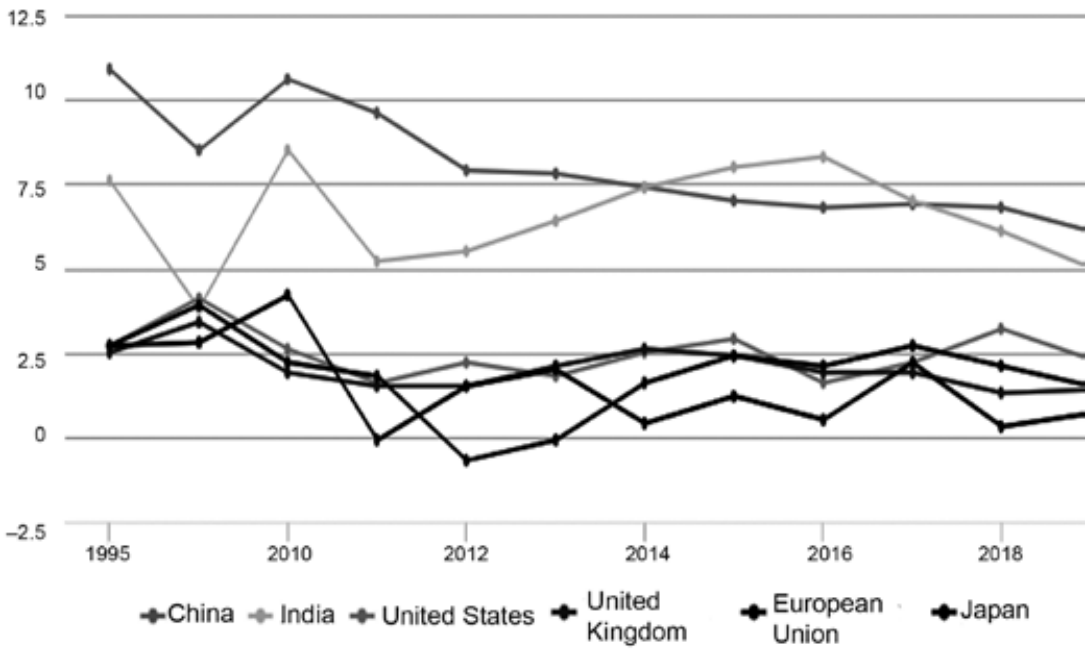

Figure 1.1 GNP growth rates for major economies

countries has exceeded that of the high-income countries. As a result of the poor countries catching up, the rift between them and the rich ones - which had been growing steadily for centuries - started to narrow. This trend reversal reflects not a sudden weakness of the rich countries, but rather the willingness and ability of a growing number of low-income countries to create and protect growth-oriented policies and institutions. There is little doubt that rich countries, including those of the EU, will lose in comparative economic weight to States such as India and China. Yet, the data in Figure 1.1 do not support the Brexiteers' view that the EU is declining or even falling apart in the manner of the Soviet Union, the paradigmatic example of a failed economy. ${ }^{28}$ There is no doubt that huge differences in economic development exist and persist between the members of the EU. However, the ten formerly poor communist countries have performed particularly well since the mid-1990s. Germany's aggregate trade volume with only three of them - Poland, Czechia and Hungary - was higher in 2019 than that between Germany and the USA, China or France. Italy, however, is in a long-standing state of stagnation, with GDP in 2019 not

28 Soros, 'The EU looks like the Soviet Union in 1991 - on the verge of collapse', The Guardian Online of 12 February 2019, available at www.theguardian .com/commentisfree/2019/feb/12/eu-soviet-union-european-elections-george-soros, last accessed 23 September 2020. 
exceeding that of 2004. During the euro crisis triggered by the financial market crisis, the EU's economic performance admittedly lagged behind that of other rich countries, including the USA, the UK and Japan. But all in all, there is no evidence supporting the view that the EU27 will always perform less satisfactorily than other high-income countries: from 1990 to 2019, per capita GDP at constant prices increased by 53.0 per cent in EU countries and by 52.6 per cent in all high-income countries taken together. This implies an annual per capita growth of 1.5 per cent in both groups of States. ${ }^{29}$ And nothing at all supports the view that a United Kingdom that negotiates international trade rules bilaterally with the new (and the old) rich countries will be more successful by itself than it would be if aligning its (often congruent) interests regarding environmental issues, consumer protection, health and safety standards and conditions for service providers with the EU.

The vision of a 'global Britain' as a boost for the UK's economy disregards the well-founded scholarly findings on the economic effects of a hard Brexit. Its overly pessimistic assessment of the EU's performance in terms of growth and economic efficiency is unjustified. It overlooks how rapidly former poorhouses like Ireland, the Visegrád and the Baltic countries have developed as members of the EU - in comparison to those former Soviet republics such as Belarus, the Ukraine, or Russia itself, which stayed away from it. Whatever the motivation for a hard Brexit may be, its proponents cannot cite sound economic arguments.

\subsection{An Uneaten Pie}

At the time of writing, optimism about the post-Brexit negotiations, and with it the odds of a not-so-hard British divorce from the EU, had waned. The possibility of failure to avoid a hard Brexit posed an analytical puzzle for economic analysis, as Roland Kirstein shows in his game-theoretical analysis of Brexit negotiations in this volume. Avoiding a hard Brexit and achieving a negotiated solution could yield economic gains for both the UK and the EU, as shown by the empirical studies mentioned above. The situation is akin to the bargaining problem for which John Nash provided a powerful economic model that gives room to an efficient and fair solution..$^{30}$ In its popularised version, a pie must be shared between two persons; if they fail to agree on a repartition, none of them gets a piece. To stay with the metaphor, the Brexit pie is filled with economic boon that no one would reap absent an agreement. Nash assumed that both

29 Based on data from the World Bank's World Development Indicators.

30 Nash, The Bargaining Problem, Econometrica, 1950, pp.155-62. 
parties share self-evident views about how to distribute the pie, determined by rationality, efficiency, symmetry and independence.

\section{WHY THE SINGLE MARKET IS NOT A BREXIT OPTION}

As Kirstein shows, the reason underlying the looming failure of the Brexit negotiations is a principal-agent problem, in the voting mechanisms. It blocks a Nash-type solution to the bargaining problem, which would require the negotiators to strive to maximise the total utility of their principals. Yet even if they did, the Brexit negotiations would be extremely complex and difficult. In this section we focus on those difficulties.

The most comprehensive cooperation next to full EU membership would have been the emulation of the single market, with free flow of goods, persons, services and capital. The free flow of goods in the single market necessitates common standards regarding consumer protection, product safety, environmental protection, labour markets, financial regulation, human rights, animal welfare, taxation and state aid. At the same time, and as long as the Member States comply with these, the principle of mutual recognition prohibits a Member State from rejecting products from other Member States on the grounds that its own national standards have not been met. ${ }^{31}$ The Commission and the ECJ monitor whether a Member State may exceptionally ban the import or the sale of a foreign product (see Art. 36 TFEU). As for the provision of services, which follows a similar pattern - now enshrined above all in the 2006 Services Directive ${ }^{32}$ - the qualification of the foreign service provider must also be considered. For many professions, the 2005 Directive on the Recognition of Professional Qualifications determines the qualifications that give foreign workers or service providers temporary (freedom to provide services) or permanent (freedom of establishment) access to other EU Member States. ${ }^{33}$ It goes without saying that here again, the Commission and the ECJ

31 E.g. EFTA Court, Judgment of 12 September 2011, E-16/10, rec. 40, available at https://eftacourt.int/download/16-10-judgment/?wpdmdl=1255, last accessed 23 September 2020; on the reception of this principle within the EEA, Pétusson in Arnesen/Fredriksen/Graver/Mestad/Vedder, EEA Commentary, 1st edition 2018, Art. 11 , rec. 8; reintroducing this principle through a bilateral agreement between the UK and the EU was an idea in British financial circles: Hellwig, The Effects of Brexit on the Law of Companies and Financial and Legal Services in Europe: A Summary Overview, European Company and Financial Law Review, 2017, p.260.

32 Directive 2006/123/EC of the European Parliament and of the Council of 12 December 2006 on services in the internal market, OJ L 376, pp.36-68.

33 Directive 2005/36/EC of the European Parliament and of the Council of 7 September 2005 on the recognition of professional qualifications, OJ L 255, pp.22-142. 
watch over the Member States' compliance with such rules of (secondary) EU law. All this explains why the emulation of the single market in the EU-UK relations after Brexit is not a viable option for the Brexiteers, who reject these centrepieces of the single market as well as the jurisdiction of the European Court of Justice.

\subsection{The Immigration Issue, Pressure on Wages of Low-Skilled Workers}

As low-income and low-wage countries, Poland, Hungary, Czechia, Slovakia, Slovenia, Lithuania, Latvia and Estonia, with an aggregate population of 75 million, joined the EU in 2004. In the preceding negotiations, several countries had insisted on an interim period in which Member States could restrict the free inflow of persons from these countries for up to seven years, which was eventually granted. ${ }^{34}$ The UK was one of only three Member States to fully open its labour market when new countries joined the EU in 2004. One important reason for the outcome of the Brexit referendum was the immigration of more than a million workers from the formerly communist Member States. While not significantly affecting the average wage rate, the influx indeed had a negative impact on the wages of low-skilled domestic workers, plumbers, agricultural workers, care providers, waiters, cleaners or clothing cutters. ${ }^{35}$ Although the effect did not exceed 3 per cent, it contributed to EU-scepticism among Brits (especially in the structurally weak areas of Northern England, which had suffered rather than profited from globalisation), many of whom believed that European integration failed to properly reflect their interests.

When the former British government realised that a deceleration of immigration was politically necessary to maintain political support for staying within the EU, it asked the EU to endorse restrictions on the free movement of workers, which the EU rejected. Any major restrictions would likely have necessitated an amendment of the TFEU (Art. 45), which in turn would have required the ratification of the amendment by all Member States after consent by all parliaments. While the European institutions' refusal to yield to the UK's wishes may be explained by their fear of the internal market eroding, it also reveals a structural inflexibility and weakness of decision-making. If

34 Technically this was regulated by annexed transitional arrangements to the accession treaty: see for an evaluation of its impacts European Commission, Report on the Functioning of the Transitional Arrangements set out in the 2003 Accession, $\operatorname{COM}(2006) 48$ final, available at https://eur-lex.europa.eu/LexUriServ/LexUriServ.do ?uri=COM:2006:0048:FIN:EN:PDF, last accessed 23 September 2020.

35 Nickell/Saleheen, The Impact of Immigration on Occupational Wages: Evidence from Britain, Bank of England, Staff Working Paper No. 574, 2015. 
a member country encounters political problems that require swift decisions and the suspension of some TFEU rules for a limited period, there is simply no such option available, as the hurdles for a (lengthy) treaty amendment procedure seem unsurmountable. This is an important reason why many Brits no longer consider the single market a political option.

\subsection{No Role for the Court of Justice of the European Union (ECJ)}

The lines of conflict extend way beyond the economic costs and benefits Brexit has in store, and beyond visions of reviving past national glory. The British government's firm rejection of any future role for the ECJ seems to be the most important non-economic issue of Brexit.

Even though Britain is reluctant to keep, or reintroduce, full free movement of all persons (apart from credit institutions), it might wish to retain the single market as regards goods and capital. If so, the UK would however be required to accept the respective principles of European primary and secondary law, even though it is no longer an EU Member State. As such, it would not be directly involved in EU law-making or the staffing of the European Court of Justice, which interprets those EU rules. Norway, Iceland and Liechtenstein have decided to accept this prerogative of the ECJ, with the court that is competent for them - the EFTA Court - being somewhat aligned to the ECJ. ${ }^{36}$ Even Switzerland did, although it is not directly subject to ECJ jurisdiction.

The present UK government denies any future role of the European Court of Justice, attaching great value to British sovereignty and autonomy. In a government brochure of February 2020 describing the UK's approach to Brexit negotiations, the text categorically rejects, no less than three times, any role the Court of Justice of the EU could possibly assume in future relations: ${ }^{37}$

It is a vision of a relationship based on friendly cooperation between sovereign equals, with both parties respecting one another's legal autonomy and right to manage their own resources as they see fit. Whatever happens, the Government will not negotiate any arrangement in which the UK does not have control of its own laws and political life. That means that we will not agree to any obligations for our

36 On the nature and functions of the EFTA Court see Bjørgan in Arnesen/ Fredriksen/Graver/Mestad/Vedder, EEA Commentary, 1st edition 2018, Part III, rec. 1 et seq.

37 HM Government, 'The Future Relationship with the EU - The UK's Approach to Negotiations', February 2020, available at https://assets.publishing.service.gov .uk/government/uploads/system/uploads/attachment_data/file/868874/The_Future _Relationship_with_the_EU.pdf, last accessed 23 September 2020. 
laws to be aligned with the EU's, or for the EU's institutions, including the Court of Justice, to have any jurisdiction in the UK. (Section 5)

All these agreements should have their own appropriate and precedented governance arrangements, with no role for the Court of Justice. (Section 6)

The arrangements will reflect the regulatory and judicial autonomy of the UK and accordingly there will be no role for the Court of Justice of the European Union in the dispute resolution mechanism. (Ch. 32, 83 (1))

The British side regards any future involvement of the ECJ as being beyond their 'red line'.$^{38}$ If this line cannot be crossed, the continuation of a single market between the EU and Britain - even if the free movement of persons is exempted - is ruled out for the foreseeable future. For the EU will not agree to take the interpretation of the applicable freedoms out of the ECJ's hands where they apply to a third country - and incur the risk of imbalances in their interpretation.

\subsection{The Power and Role of the ECJ in Promoting European Integration}

The ECJ has given EU law its present shape by interpreting and even extending it on the grounds of full effect (or effet utile), ${ }^{39}$ especially as regards the freedoms. One of the most striking emanations of that effet utile is the liability of Member States to citizens for breaches of EU law (of all sorts), on which the Treaties remain silent but which the Court considers indispensable for the effectiveness of EU law. ${ }^{40}$ The judges established the primacy of EU law over national law, including national constitutional law, as early as 1964 - long before the UK acceded to the EC - and have ever since worked on its sophistication. ${ }^{41}$ They have thereby strengthened the role of citizens in the enforcement of EU law beyond the mere wording of the Treaties. The ECJ, in 1963 and more pointedly in 1964, declared European law to be a field of law that was

38 Press statement by Michel Barnier following Round 6 of the negotiations for a new partnership between the European Union and the United Kingdom, 23 July 2020, available at https://ec.europa.eu/commission/presscorner/detail/en/STATEMENT_20 1400, last accessed 23 September 2020.

39 Based on Art. 4 (3) TEU, see in more detail Blanke in Blanke/Mangiameli, The Treaty on the European Union (TEU), Art. 4 rec. 95; European Court of Justice, Judgment of 29 November 1956, 8-55, p.312; Judgment of 21 February 1991, C-143/88 and C-92/89, ECLI:EU:C:1991:65, rec. 1.

40 European Court of Justice, Judgment of 19 November 1991, C-6/90 and C-9/90, ECLI:EU:C:1991:428, rec. 3 - Francovich.

${ }_{41}$ Blanke in Blanke/Mangiameli, The Treaty on the European Union (TEU), 1st edition 2013, Art. 4 rec. 1, 55, 87. 
distinct from traditional public international law, ${ }^{42}$ due, inter alia, to its direct effect and the conferral of rights and duties also upon private persons, rather than just States. In some cases, the Court was driven by sheer necessity: when it was introduced by the ECJ, the liability for breaches of EU law was directed against non-compliant Member States, for whom violating EU law (especially by not transposing a Directive) was often financially and politically profitable. The Court has also extended the scope of competition law by accepting the 'extraterritorial' effects doctrine the Commission had assigned to it. ${ }^{43}$

The present role of the ECJ may be explained by the economic theory of court power. Its basic argument is that the power of a supreme court in developing judge-made law (which in many cases does not coincide with the political goals of the parliamentary majority) depends on how easily parliament can override that judge-made law by enacting new legislation. ${ }^{44}$ The latter becomes more difficult by the same degree as veto rights may impede decision-making in parliament. Economists hold that where numerous political veto positions exist, supreme courts need not be afraid of their judge-made law being invalidated by political bodies - and that they can hence intensify their activities in shaping the law without restraint. By contrast, supreme courts in countries with a bold parliament tend to be much more cautious. This theory may explain the observable differences between the ECJ and the British Supreme Court.

To override a judge-made rule which emerges from the ECJ's interpretation of the TFEU requires an amendment of the treaty and thus unanimity by (now) 27 governments, and approval by all national parliaments. However, the rulings of a constitutional court can, in principle, be overridden by national law and constitutional amendment. In brief, the ECJ can decide as it pleases within the limits of doctrinal constraints and irrespective of whether the national governments or parliaments endorse its findings. Being much more powerful, its position thus differs considerably from that of national courts and from

42 European Court of Justice, Judgment of 20 February 1964, 6/64, ECLI:EU:C: 1964:66, rec. 3 - Costa/ENEL.

43 See, for example, European Court of Justice, Judgment of 6 September 2017, C-413/14, ECLI:EU:C:2017:632, rec. 42 et seq.

44 The theory of court power depending on the number of veto positions in parliament has mainly been proposed by Cooter and Ginsburg: see Cooter, The Strategic Constitution, 2000, p.356; see also Cooter/Drexl, The Logic of Power in the Emerging European Constitution: Game Theory and the Division of Powers (1994) International Review of Law and Economics 14:307-26; Cooter/Ginsburg, Comparative Judicial Discretion: An Empirical Test of Economic Models (1996) International Review of Law and Economics 16:295-314. In Germany, Grimm expressed similar views on the role of the ECJ: Grimm, Europa ja - aber welches? Zur Verfassung der europäischen Demokratie [Europe, yes, but which one? On the constitution of European democracy] 2016. 
the British Supreme Court. The UK has much fewer potential veto players against overriding judge-made law, with a self-enforcing effect on the powers of parliament. This has long been discussed, and not only in Britain, where not only a quasi-legislative but also an active Supreme Court is a somewhat alien concept. ${ }^{45}$

It is safe to say that the Treaties of Rome prepared the ground for the ECJ becoming a motor of integration, and not unintentionally so. Otherwise, the founders of the EC would have given the ECJ only very limited judicial powers - and they would have kept the travaux préparatoires of the treaty negotiations accessible instead of locking them away. Not knowing the true will of the Member States, the Court is not restricted by it in interpreting the Treaties, as it would be under public international law (Art. 31 (1), (2) VCLT). ${ }^{46}$ In other terms, European integration trumps national sovereignty when it comes to treaty interpretation. The UK - which joined the Union in 1973, when this position of the ECJ was already full-fledged - cannot claim to have been taken by surprise. The ECJ's landmark decisions establishing the principles of the primacy and direct effect of European law had long been taken.

However, criticism of the ECJ has grown over time. When the Court was established, the EEC comprised six Member States. With the multiplication of their number - reaching a maximum of 28 in 2013 - but also with the increasing number of EU policies, the ECJ became mightier. National supreme courts and constitutional courts are taking pains to defend the core values of their constitutions against ECJ interference, which they regard as a threat. The German, Polish and French Constitutional Courts have strengthened the role of their respective parliaments in the transfer of national competences upon the EU. Ireland had respect for some of its core constitutional values, such as the prohibition of abortion or neutrality, granted through the 2012 Protocol on the concerns of the Irish people on the Treaty of Lisbon ${ }^{47}$ (although the

45 Only in 2005 was the 'new Supreme Court for the United Kingdom' created by the Constitutional Reform Act 2005 (c. 4), available at www.legislation.gov.uk/ ukpga/2005/4/data.pdf, last accessed 24 September 2020; its jurisdiction encompasses civil, criminal, family and military cases: see Courts and Tribunals Judiciary, The Supreme Court, available at www.judiciary.uk/about-the-judiciary/the-justice-system/ the-supreme-court/, last accessed 23 September 2020.

46 Dörr in Dörr/Schmalenbach, Vienna Convention on the Law of Treaties, 2nd edition 2018, Art. 31 rec. 1 et seq.

47 2013/106/EU: European Council Decision of 11 May 2012 on the examination by a conference of representatives of the governments of the Member States of the amendment to the Treaties proposed by the Irish Government in the form of a Protocol on the concerns of the Irish people on the Treaty of Lisbon, to be annexed to the Treaty on European Union and to the Treaty on the Functioning of the European Union, and not to convene a Convention, OJ L 60, pp.129-30. 
national ban on abortion was eventually dropped, in 2018 , by a constitutional amendment). In 2020 the German Constitutional Court, which had long sought to maintain a balance with the ECJ that was, however, not free of tension, for the first time rejected a legal opinion the ECJ had delivered to that Court as ultra vires ${ }^{48}$ (as had corresponding courts in Denmark and Czechia before $\mathrm{it}^{49}$ ). While in Germany controversies arose as to whether the judgment was well founded, ${ }^{50}$ many scholars agree that some EU institutions - especially the ECJ, but also the European Central Bank (whose purchasing policy the controversial judgment concerned) - are increasingly escaping democratic control - by both national and European institutions. ${ }^{51}$ Although the UK, not being part of monetary union, is unaffected by any judgment of the ECJ regarding the powers of the European Central Bank, the Court's decisions and the resulting encroachment upon national sovereignty must have alarmed it all the same. For a country that attaches great importance to the 'sovereignty of parliament', treading that judicial path cannot be a desirable option.

48 German Constitutional Court, Judgment of 5 May 2020, 2 BvR 859/15, 980/16, 2006/15, 1651/15.

49 Danish Supreme Court, Judgment of 20 February 2013, Case No. 199/2012, U 2013.1451H, p. 1518; for more details see Krunke/Baumbach, The Role of the Danish Constitution in European and Transnational Governance, in National Constitutions in European and Global Governance: Democracy, Rights, the Rule of Law, 2019, pp.273 et seq.; Constitutional Court of the Czech Republic, Judgment of 20 March 2007, Pl. 4/06: for more details see Komárek, Playing with Matches: The Czech Constitutional Court's Ultra Vires Revolution, Verfassungsblog, 22 February 2012, available at https://verfassungsblog.de/playing-matches-czech-constitutional-courts-ultra-vires -revolution/, last accessed 23 September 2020.

50 Nettesheim, Neue Juristische Wochenschrift, Das PSPP-Urteil des BVerfG - ein Angriff auf die EU? [The German Constitutional Court's PSPP judgment - an attack on the EU?], 2020, pp.1631 et seq.; Ludwigs, Europäische Zeitschrift für Wirtschaftsrecht, Scherbenhaufen oder Chance? [Shambles or opportunity?], 2020, pp. 530 et seq.; for a critical perspective on this judgment also see Kämmerer, Ein problematisches Urteil [A problematic judgment], Frankfurter Allgemeine Zeitung Einspruch of 6 June 2020, available at www.faz.net/einspruch/bverfg-zum-anleihenkauf-ein-problematisches -urteil-16804066.html, last accessed 23 September 2020.

${ }_{51}$ Amtenbrink, The Democratic Accountability of Central Banks, 1990; Mancini/ Keeling, The Modern Law Review, Democracy and the European Court of Justice, 1994, pp.175 et seq.; Fromage, Maastricht Journal of European and Comparative Law, 2019, available at https://journals.sagepub.com/doi/full/10.1177/1023263X18822788, last accessed 23 September 2020; Rumler-Korinek, Kann die Europäische Union demokratisch ausgestaltet werden? [Can the European Union be structured in a democratic manner?], Europarecht 2003, pp.327 et seq.; on the role of the European Parliament Rittberger, 'Integration without Representation?', 2014. 


\section{IS A HARD BREXIT THE BETTER SOLUTION?}

In the wake of a hard Brexit, with no subsequent arrangement to 'soften' it, the political and economic relations between the EU and UK would automatically be governed by GATT/WTO rules only. Despite the currently low level of customs duties on industrial products (well below 5 per cent), empirical studies indicate the end of its participation in the single market would entail huge economic losses for the UK (as described above in section 2). At first glance, the WTO option appears to be the most comfortable and least controversial way of organising future EU-UK trade relations, since no 'level playing field' for the international trade of goods is required and WTO law and panel and Appellate Body decisions do not interfere with sovereignty to the same degree as EU law, with its direct effect. WTO law therefore appears to match the UK's preference for more national sovereignty and autonomy.

In a nutshell, the GATT obliges WTO members to remove non-justifiable trade barriers except for tariffs, which it seeks to reduce ('tariffs only'). Foreign 'like products' (in general, substitutable ones) enjoy national treatment, that is, they must not be discriminated against. In principle, no importing State may impose restrictions on grounds of production methods or legal standards governing the production. Exceptions to this default rule of national treatment are enshrined, inter alia, in GATT Art. XX, which permits import restrictions 'necessary to protect public morals' or 'necessary to protect human, animal or plant life or health'. The wording of these rules strikingly coincides with Arts 30 and 36 TFEU, which obviously emulate Art. XX GATT. However, absent a powerful executive body (the Commission) and an ECJ that has shaped those EEC/TFEU rules into directly applicable individual rights, the GATT provisions entirely lack the strength of the European rules.

Yet the WTO would not be the best of all trade worlds for the British. While it is true that EU law would yield to international law, the resilience of EU law in the face of a rather weak international trade regime should not be underestimated. For example, the EU holds that under its precautionary principle, import restrictions may also be imposed where scientific evidence is not available (yet). This triggered a conflict with Canada and the USA when the EU imposed a ban on beef from cattle treated with growth hormones. The EU lost the case in the WTO but refused to lift the import ban and instead accepted retaliation. Even though such practices may not comply with international law, they may nevertheless be in line with EU standards, if the ECJ is to be believed. ${ }^{52}$ Thus, the UK could find it difficult to impose on the far mightier

52 European Court of Justice, Judgment of 30 September 2003, C-94/02, ECLI:EU: C:2003:518, rec. 71 . 
EU respect for WTO law as Britain - and possibly even the Dispute Settlement Body of the WTO - sees it. As already mentioned, decisions by panels and even by the Appellate Body do not in and of themselves carry a legal obligation for the losing party, but only highlight in a declaratory manner obligations pursuant to the relevant GATT Treaty. The winning party may then impose sanctions (but only the ones permitted by that treaty) on the losing party. While the ECJ has at least some instruments at hand to enforce its judgments (such as pecuniary sanctions), no such levers exist in WTO law, where countermeasures remain a matter for the States.

It should be added that the WTO regime also encompasses a legal framework for the provision of services - the General Agreement on Trade in Services (GATS). However, as Friedemann Kainer underpins in his contribution to this volume, GATS is far less substantial than GATT in that, unlike the latter, it does not provide for the general liberalisation of trade irrespective of its sector; liberalisation depends on the parties' voluntary commitments, which are confined to specific service markets. In other words, the States concerned must determine whether, how and to what extent a service can be traded internationally. This requires a lengthy process of submitting and certifying trade 'schedules'. Quite obviously, GATS provides leverage for the top item on the British wish list - access to the Union's financial markets ('passporting') only to the extent that the EU makes corresponding concessions under GATS.

Even if the UK finds all this desirable, it must bear in mind that the WTO system is becoming increasingly dysfunctional. As Jörg Philipp Terhechte points out in this volume, it is even questionable whether WTO law provides any fallback position for the UK in the case of a hard Brexit, for the two most important players are currently doing their best to disable it. The USA vetoes the appointment of judges to the Appellate Body, ${ }^{53}$ where of six of seven posts are now vacant. Thus, the Appellate Body is currently paralysed and unable to take the decisions that would be required to give panel decisions legal authority - and without a decision of the Appellate Body, the UK would not be entitled to countermeasures, either. The other problem is disrespect of the substantial WTO law. In China, state-owned or state-controlled and heavily subsidised firms sell their products worldwide without observing the WTO rules on state aid contained in the Agreement on Subsidies and Countervailing Measures ( $\mathrm{SCN})$. Thus, in international trade relations, law is losing ground to lawlessness. The WTO system is also unable to modernise its rules, for

53 Felbermeyer, Europa und die globale Wirtschaftsordnung [Europe and the global economic order], Kiel Institute for the World Economy, Kiel Focus, 2020, available at www.ifw-kiel.de/de/publikationen/kiel-focus/2020/europa-und-die-globale-wirt schaftsordnung-0/, last accessed 23 September 2020. 
instance, to accommodate digital trade. A growing share of international trade is subject to preferential trade agreements with specific dispute resolution tribunals outside of the WTO framework, making it increasingly superfluous. ${ }^{54}$

The WTO ocean is vast, but its waters are unruly - not to mention the numerous shallows. The relatively small and mostly service-oriented UK will lack the economic weight to push forward the development of new and improved trade rules that would serve its national interest unless big players such as the USA, the EU, China, India and Japan join in.

\section{PROBLEMS OF A FREE TRADE ZONE}

If neither a de facto prolongation of the single market nor the GATT/WTO system in its present state is sufficiently attractive to the UK, a Free Trade Zone or Association would lend itself as a middle ground option. It would not extend to customs duties in a comprehensive manner and therefore would preserve British autonomy in negotiating bespoke trade (and customs) agreements with other countries. Both sides have been negotiating on a free trade agreement since March 2020, so far (September 2020) without success. ${ }^{55}$ They seem to be willing to agree on a State-to-State dispute resolution mechanism, which can effectively settle disputes and includes an enforcement mechanism, ${ }^{56}$ circumventing the aforementioned weaknesses of WTO law dispute settlement.

However, the negotiating parties are divided on the scope of that agreement. The EU aspires to a comprehensive agreement, with a level playing field for trade with Britain ${ }^{57}$ and common standards on social security, environmental protection, climate change management, taxation, state aid control, competition law, control of state-owned enterprises, data protection and sustainable development. ${ }^{58}$ This would be akin to the single market as we know it. The

54 Ibid.

55 Speech by Michel Barnier to the students at ESCP Europe: Cooperation in the Age of Brexit, Brussels, 26 February 2020, available at https:/ec.europa.eu/ commission/presscorner/detail/en/SPEECH_20_340, last accessed 23 September 2020.

56 HM Government, 'The Future Relationship with the EU - The UK's Approach to Negotiations', February 2020, available at https://assets.publishing.service.gov .uk/government/uploads/system/uploads/attachment_data/file/868874/The_Future _Relationship_with_the_EU.pdf, last accessed 23 September 2020.

57 Press statement by Michel Barnier following Round 6 of the negotiations for a new partnership between the European Union and the United Kingdom, 23 July 2020, available at https://ec.europa.eu/commission/presscorner/detail/en/STATEMENT_20 _ 1400, last accessed 23 September 2020.

58 European Commission, Task Force for Relations with the United Kingdom, Draft text of the Agreement on the New Partnership with the United Kingdom, 18 March 2020. 
UK, however, according to a policy paper presented in March 2020, looks to the WTO framework, which it considers to interfere less with its sovereignty, as the guideline for a post-Brexit agreement with the EU. It argues, inter alia, that the Comprehensive Economic and Trade Agreement with Canada (CETA) was inspired by WTO law and that no comprehensive level playing field was agreed upon in CETA. ${ }^{59}$ In any event, British 'red lines' remain, namely that an agreement must not empower the ECJ in any way and must not restrict the UK's right to shape its future trade relations. The EU, however, strives for a tailor-made free trade agreement with Britain - an agreement that cannot merely emulate CETA, not least insofar as trade volume between the EU and the UK is nine times as high as between the EU and Canada. As chief EU negotiator Barnier put it, a 'Singapore on Thames', ${ }^{60}$ with rather low wages and low labour, social, environmental and animal welfare standards, in the centre of an economic zone with low or no tariff barriers, is not desirable, as it could entail a race to the bottom that harms the single market. Another reason why even the British do not aim to simply copy CETA is that they want their financial industry to be given privileged access to the EU service markets, which CETA does not grant Canada. The political and legal obstacles of this privileged access, commonly referred to as 'passporting', will be dealt with further below.

\section{A NOTE ON 'FAIR INTERNATIONAL TRADE AND LEVEL PLAYING FIELD'}

The EU insists on a 'level playing field' and wants the UK to indirectly remain a rule-taker of European standards, including production methods - which the UK rejects. Why do both sides insist on their positions? To approach this question, we must clearly distinguish between upholding ethical standards in production for ethical reasons, on the one hand, and for purely commercial reasons (fairness standards in international trade), on the other. Ethical minimum standards of human rights are part of the Strategic Partnership Agreement (SPA) with Canada, which is not a trade agreement in itself but is

59 The CETA Agreement includes substantive standards on labour, the environment and human rights. But 'these obligations are enforced only by means of an (at most) morally suasive report': see Bartels, Human Rights, Labour Standards and Environmental Standards in CETA, Legal Studies Research Series, University of Cambridge, Paper No. 13/2017, p.16.

${ }_{60}$ Speech by Michel Barnier to the students at ESCP Europe: Cooperation in the Age of Brexit, Brussels, 26 February 2020, available at https://ec.europa.eu/ commission/presscorner/detail/en/SPEECH_20_340, last accessed 23 September 2020. The metaphor is inappropriate as Singapore is now one of the world's richest countries, with high wages and high labour, safety and environmental standards. 
closely associated with CETA. In 2011, the European Council suspended an agreement with Syria in which both sides had agreed on the principles of the United Nations Charter. ${ }^{61}$

We cannot indulge here in discussion about the scope of universal ethical values. But we can ask whether joint minimum standards on the environment, labour conditions, taxes or animal welfare are necessary for a trade agreement, as advocated by the EU. ${ }^{62}$ We think the EU argument is partly right but mostly incorrect in raising concerns about trade - at least in an exclusively economic perspective. More lax UK labour standards, leading to shrinking labour costs and lower prices for British products and services, need not undermine the competitiveness of EU products or services - neither in the EU itself nor on the British market. While British products would become cheaper than EU products, EU exports to Britain would decline and British exports to the EU increase; the British pound would appreciate due to the increased demand; and European currencies would depreciate accordingly. In other terms, the competitiveness of EU products may partially be restored through exchange rate mechanics. While individual companies and industries in Britain and the EU will certainly be affected, the overall competitiveness of EU and British products may not be. This is also true for labour standards, as much as for animal welfare and environmental standards - and even for the regulation of night flights from and to an international airport, and the resulting damages and welfare losses. ${ }^{63}$

Admittedly, countries with a trade surplus could manipulate their exchange rates to avoid the appreciation of their currencies and the resulting downturn of exports, but such a problem could arise independently of minimum standards on production modalities. Yet, a free trade agreement is no protective shield against political misuse of the exchange rate for a 'beggar my neighbour policy' (Joan Robinson) to boost exports and employment during an economic crisis at the expense of employment in other countries. ${ }^{64}$

${ }_{61}$ Bartels, Human Rights, Labour Standards and Environmental Standards in CETA, op. cit., p. 10 .

62 In a public statement on 5 June 2020, Chief Negotiator Michel Barnier described the rationale for production standards as 'rules of economic and commercial fair play': available at https://ec.europa.eu/commission/presscorner/detail/en/speech_20_1017, last accessed 23 September 2020.

${ }^{63}$ Schäfer/Lantermann, Choice of Law from an Economic Perspective, in Basedow/ Kono, An Economic Analysis of Private International Law, 2006, pp.87 ff.

64 Robinson coined the word for a foreign trade policy that artificially creates export surpluses and a resulting high level of employment at the cost of reducing employment in the country's trading partners. This policy, sometimes combined with wage deflation, was first observed during and following the Great Depression of 1929: 
As for tax law, the UK has some potential to inflict harm on the EU after leaving the single market by reducing corporate income tax rates, as Fuest and Sultan have shown. ${ }^{65}$ At present, while discriminatory taxation is prohibited in the EU, corporate income tax rates are not harmonised. In some countries, including the UK, the corporate income tax is much lower than in Germany, France or Italy. The British tax rate fell from 50 per cent in the early 1980s to below 20 per cent in 2017. Since Member States may fix their tax rates autonomously, Brexit will not affect this practice much. However, what will cease to apply at the end of the transition period is the prohibition of discriminatory taxation (cf. Art. 110 TFEU for goods and the general provision of Art. 49 TFEU for persons). While the UK will likely profit from the continued application of that principle by the EU27 to all products in circulation (including those of British origin), the UK itself is then free to use discriminatory taxation to protect its own industries or even single firms.

\section{BREXIT, THE FINANCE INDUSTRY AND SERVICES IN GENERAL}

Britain was the first industrialised country in the world; similarly, it has been a pioneer of financial market transactions and services in the EU and has remained the unbeaten champion in this field, with London as its financial hub - whose importance for the British, European and global economy cannot be overstated. ${ }^{66}$ In 2017, financial services worth $£ 26$ billion were exported to the UK (43 per cent of all UK financial service exports), while imports from the EU were only worth $£ 5$ billion ( 34 per cent of UK imports of financial services) ${ }^{67}$ Although Europe and especially Germany have been moving towards a more capital market-oriented financial system since the 1980s, large differences remain between British and continental financial markets (and between the degrees of sophistication of their regulation!). ${ }^{68}$ British financial

'Beggar-My-Neighbour Remedies for Unemployment', in 'Essays in the Theory of Employment', 1947.

65 Fuest/Sultan, How Will Brexit Affect Tax Competition and Tax Harmonization? The Role of Discriminatory Taxation, CESifo Working Paper No. 6807, 2017.

${ }_{66}$ Financial services accounted for 6.9 per cent of Britain's output in 2018. The number has declined from its peak of 9.6 per cent in 2009: see Rhodes, House of Commons Library, Financial Services: Contribution to the UK Economy, Commons Library Briefing, 31 July 2019. In 2019, 1.1 million people worked in financial services: Statista, available at www.statista.com/statistics/298370/uk-financial-sector -total-financial-services-employment/, last accessed 23 September 2020.

67 Rhodes, ibid, p.5.

68 Rajan/Zingales, 'The Changing Character of European Markets', NBR Working Paper Series, Working Paper 9595, p.7. 
institutions are strong in the fields of equity market capitalisation, financial wholesale, asset management, investment funds, trade in derivatives, complex insurance, investment banking, the provision of market infrastructure and FinTech. Market-oriented as it is, Britain has a comparative advantage in providing, and regulating, financial services in Europe, which will be difficult for financial institutions in the EU27 to replace, as Georg Ringe shows in this volume. The UK capitalises on economies of scale, that is, the positive agglomeration effect of a large financial centre, whose expansion reduces rather than increases the average cost per unit of service. ${ }^{69}$ As an EU member, Britain attracted financial institutions not only from the EU but from the entire world, which succumbed to, and thereby reinforced, London's attractiveness. By holding a British bank licence, the UK branches of these third-country providers had the right to provide financial services throughout the EU without having to apply for national permits as long as the UK was its member (and during transition) - the famous 'passporting'. ${ }^{70}$

A soft Brexit emulating the single market could have left this institutional arrangement intact, giving Britain a status akin, or even superior, to Norway, Iceland or Liechtenstein, who enjoy (limited) rights of passporting. Third countries, that is, countries that have not accepted the freedoms of the single market, are generally not admitted to passporting in the proper sense of the term; they must apply for 'service visas' in the individual EU Member States - which are issued on the condition that the financial market rules of the country of origin are 'equivalent' to those of the EU. ${ }^{71}$ Third-country equivalence (3CE) with respect to a specific financial market is determined by the Commission, but de facto by ESMA (the European Securities and Markets Authority). If 3CE has been established, a third-country provider can apply to the competent national financial authorities (possibly all 27) for a licence covering the proposed service. ${ }^{72}$

69 See esp. Armour, Brexit and Financial Services, Oxford Review of Economic Policy, 2017, pp.S54-S69, with further literature.

70 On this term Kinander, The Norwegian Model for Access to the European Financial Markets: The Principles and Practicalities of the EEA States' Solution to the Passporting Issue in Light of Brexit, European Company and Financial Law Review, 2018, pp.238 et seq.; Hellwig, The Effects of Brexit on the Law of Companies and Financial and Legal Services in Europe: A Summary Overview, European Company and Financial Law Review, 2017, p.258.

71 Kinander, The Norwegian Model for Access to the European Financial Markets: The Principles and Practicalities of the EEA States' Solution to the Passporting Issue in Light of Brexit, European Company and Financial Law Review, 2018, p.251.

72 Armour, Brexit and Financial Services, Oxford Review of Economic Policy, 2017, p.65; Kämmerer, Europeanisation of Financial Markets Regulation in Times of Brexit, European Company and Financial Law Review, 2017, p.642. 
Third-country access - a minor form of passporting - can still be granted to British financial institutions if Britain does not participate in the single market, even in the hardest of all possible Brexits. However, the UK has asked for more: proper passporting without recognition of the freedoms. Not surprisingly, this was declined by the EU - not only because passporting, enabling the provision of a financial service, is an emanation of the single market, ${ }^{73}$ which is considered indivisible, but also because the EU sees no compelling reason why it should concede to the British what it had refused another financial hub, namely Switzerland. ${ }^{74}$ It is questionable whether long-term financial relations can be built upon third-country access in an efficient way - and whether the $\mathrm{UK}$, which at present is recognised as 'the most equivalent country in the world', ${ }^{75}$ will (want to) preserve that equivalence. Full British sovereignty regarding its regulatory law means that those laws may be changed at any time. Also, 3CE is decided unilaterally; the EU can grant and withdraw that privilege (the Treaty grants third-country providers only the free movement of capital, not the freedom to provide - financial and other - services). Furthermore,

73 Prüm, Brexit: Options for Banks from the UK to Access the EU Market, Europäische Zeitschrift für Wirtschaftsrecht, 2017, p.988; Kämmerer, Europeanisation of Financial Markets Regulation in Times of Brexit, European Company and Financial Law Review, 2017, p.641.

74 This possibility was the official UK government position in the negotiations: 'The UK and the EU have committed to carrying out unilateral equivalence assessments for financial services, distinct from the CFTA. The fact that the UK leaves the EU with the same rules provides a strong basis for concluding comprehensive equivalence assessments before the end of June 2020.' HM Government, 'The Future Relationship with the EU - The UK's Approach to Negotiations', February 2020, Section 63, available at https://assets.publishing.service.gov.uk/government/uploads/ system/uploads/attachment_data/file/868874/The_Future_Relationship_with_the_EU .pdf, last accessed 23 September 2020. This was however not accepted, mainly because it contains no future commitments on the UK side. On 26 February 2020 the newspaper The Independent quoted chief EU negotiator Barnier with a statement that came close to an outright rejection: 'Why should we accept the profits stay in London while the EU carries the risks? The UK may not want to be a rule-taker. OK, but we don't want to be the risk-taker. When the next financial crisis strikes, who will foot the bill? I doubt the UK will foot it for the EU. That's why the EU must take responsibility for its financial regulation, supervision and financial stability.' See 'Financial services companies must accept EU regulations if they want access to continental markets post-Brexit, Barnier says', The Independent Newspaper Online of 26 February 2020, available at www .independent.co.uk/news/uk/politics/brexit-trade-deal-eu-regulations-michael-barnier -city-london-a9361596.html, last accessed 24 September 2020.

${ }_{75}$ Quote by Nausicaa Delfas, executive director international at Britain's Financial Conduct Authority: see 'Is it worth it? UK banks question EU access after Brexit', Reuters Online of 28 October 2019, available at https://de.reuters.com/article/us-britain -eu-banks/is-it-worth-it-uk-banks-question-eu-access-after-brexit-idUSKBN1X71SM, last accessed 24 September 2020. 
the criteria for 3CE may become politicised and insofar constitute a 'moving target' ${ }^{76}$

Mathias Hanten explains in this volume what British financial service companies, as third-country actors, would have to do to benefit from 'passporting'. Under the complex legal regime, establishing an EU-based subsidiary would not be enough to escape the third-country rules; what it takes is a qualified form of establishment referred to as branch. Providers that once moved to London in order to profit from the conditions of a financial hub while at the same time enjoying passporting (as an unquestioned privilege) might decide to relocate their seat to Dublin, Paris (where the European Banking Authority moved from London), Amsterdam or Frankfurt - but they might also keep a branch in the UK which provides financial services to customers on the continent (a phenomenon known as 'back-branching', and described by Hanten in his chapter). London, however, might cease to be involved in those transactions and clearings that are directly related to the euro and the European Central Bank. (The latter had attempted to prevent those transactions from being made outside the Eurozone, but unsuccessfully so, because the UK was, after all, an EU Member State ${ }^{77}$ ). This might benefit EU financial companies but probably not non-financial ones, because costs are higher in continental Europe. Moreover, a shrinking financial sector in the UK would raise the costs per unit of service in Britain, since the benefits from agglomeration decline. All in all, Brexit would be rather a lose-lose situation regarding financial markets. A hard Brexit without passporting would, as Ringe rightfully argues, trigger private reactions in the British finance industry. ${ }^{78}$ We do not know how an innovative financial hub will react to losing its privileges on the European continent. It may well find new entrepreneurial ways of attracting business even under the rougher third-country conditions. For many decades, indeed centuries, London has been a magnetic place for money in Europe. It is unlikely to lose all of its appeal to Brexit.

A treaty-based commitment could reduce this uncertainty. ${ }^{79}$ It is, however, unclear how the British desire for autonomy in its regulation of the British financial sector can be aligned with the very nature of passporting, namely the extension of the freedom to provide services to a third country, and why the EU should accept this extension for a specific branch and a specific country

76 Armour, Brexit and Financial Services, Oxford Review of Economic Policy 2017, p.S61.

77 Ringe, The Irrelevance of Brexit for the European Financial Market, Legal Research Paper Series, Paper No 10/2017, updated January 2018.

78 Ibid, p.33.

79 Browning, Brexit and Financial Services, House of Commons, Briefing Paper Number 7628, 2019 , p.7. 
while refusing it to other financial powerhouses such as Switzerland, Hong Kong or Singapore. Georg Ringe argues in this volume that after 2020 an interplay between regulation and private activity will start to evolve. He asserts that Brexit will not end the trajectory of financial integration. In the long run - as in the past - economic necessities and political reasoning will outweigh legal formality.

The problems highlighted above are not confined to the financial sector, which is but the most emblematic of the service markets affected by Brexit. They will arise with respect to any trans-border services: aviation, telecommunications, mass media, law firms, and so on. International law does not distinguish between services provided by residents - such as the proverbial Polish plumber - and services that require only a temporary presence of the provider, if any. GATS remains an empty shell unless both sides reciprocally open their access gates to other parties. According to Friedemann Kainer, mutual access could be also achieved without formal agreements, for example by establishing a Regulatory Cooperation Office for the services concerned.

\section{BREXIT AND JUDICIAL AND SECURITY COOPERATION}

A hard Brexit would also end the intensive judicial and police cooperation between Britain and the EU. Extending far beyond criminal matters, it especially includes judicial cooperation in commercial disputes, as Giesela Rühl sets out in this volume. A tight network of EU regulations dealing with jurisdiction, recognition and enforcement of British court decisions will cease to apply at the end of the transition period. Presently, the Commercial Court in London is the venue of choice for many disputes with at least one foreign party. Its popularity is due to its use of the English language, a civil procedure that suits the interests of merchants, speedy proceedings and decisions that can swiftly be enforced throughout the EU. As Rühl points out, Brexit may jeopardise a flourishing 'industry' of commercial lawyering in London unless a special agreement paves the way for the continued and easy use of British courts for commercial disputes. Such an agreement is, however, not in sight. The UK government strategy paper of March 2020 mentions civil judicial cooperation and proposes to base it on international law and bilateral agreements, but it remains entirely silent on the role of EU law in this matter. ${ }^{80}$

80 HM Government, 'The Future Relationship with the EU - The UK's Approach to Negotiations', February 2020, Section 64, available at https://assets.publishing.service .gov.uk/government/uploads/system/uploads/attachment_data/file/868874/The_Future _Relationship_with_the_EU.pdf, last accessed 23 September 2020. 
Rühl shows how courts in France, Germany and the Netherlands are reacting to a possible legal blockade of the London courts by establishing commercial courts that better cater to the needs of the international business community, including the use of English language.

Close judicial cooperation in criminal matters within the EU relates to extradition, including the European Arrest Warrant, the fight against crimes such as money-laundering and terror financing, evidence-gathering and information-sharing. Europol and Eurojust are EU institutions based on primary (Arts 85, 86 TFEU) and secondary law. ${ }^{81}$ After the end of the transition period, cooperation with the UK in these matters can no longer be based on EU law. Without new agreements, any EU-UK cooperation would resemble that of the EU with any other third State. It would involve a case-by-case assessment of whether - for example, regarding extradition - human rights, data protection or fair procedures might be violated. Both sides agree that close cooperation in criminal matters is important and a corollary of globalisation, which leads to an increase of illegal transactions and organised crime; however, they do not agree on the legal basis. Once again, the UK rejects any role for the ECJ while insisting on its national prerogative for the protection of human rights and data. Section 31 of the 'UK approach' reads:

Cooperation will be underpinned by the importance attached by the UK and the EU to safeguarding human rights, the rule of law and high standards of data protection. The agreement should not specify how the UK or the EU Member States should protect and enforce human rights and the rule of law within their own autonomous legal systems. ${ }^{82}$

The UK seeks close cooperation in criminal matters in many fields, including data exchange for law enforcement; cooperation with Europol and Eurojust; fast-track extradition; mutual legal assistance, including asset-freezing and confiscation; fast and effective exchange of criminal records; national DNA,

81 Regulation (EU) 2016/794 of the European Parliament and of the Council of 11 May 2016 on the European Union Agency for Law Enforcement Cooperation (Europol) and replacing and repealing Council Decisions 2009/371/JHA, 2009/934/ JHA, 2009/935/JHA, 2009/936/JHA and 2009/968/JHA, OJ L 135, pp.53-114 and Council Decision of 28 February 2002 setting up Eurojust with a view to reinforcing the fight against serious crime, OJ L 63, pp.1-13; Weyembergh/Armada/Brière, The Inter-agency Cooperation and Future Architecture of the EU Criminal Justice and Law Enforcement Area, Study realised for the LIBE Committee of the European Parliament, 2014, pp.11-14.

82 HM Government, 'The Future Relationship with the EU - The UK's Approach to Negotiations', February 2020, Section 31, available at https://assets.publishing.service .gov.uk/government/uploads/system/uploads/attachment_data/file/868874/The_Future _Relationship_with_the_EU.pdf, last accessed 23 September 2020. 
fingerprint and vehicle registration data; reciprocal transfers of airline passenger records; real-time alerts on wanted persons; exchange of classified information; and arrangements on the transfer of prisoners. ${ }^{83}$ All these matters are governed by the provisions of the European Convention on Human Rights and the authoritative jurisdiction of the European Court of Human Rights (ECtHR) on those provisions. After Brexit, the UK will probably remain a member of the Council of Europe and as such it will continue to accept the jurisdiction of the ECtHR. It is therefore hard to understand why it rejects not only any role of EU law and the ECJ, but even any involvement of the ECHR in the scrutiny of a post-Brexit agreement between the UK and the EU. ${ }^{84}$

A court setting guidelines is a requirement for effective cooperation. This standard cannot be guaranteed if governments announce they will observe the highest human rights standards but delegate decisions to an arbitral tribunal, a politicised body whose members are appointed by the parties. The following example illustrates the practical importance of ECHR involvement. Recently, the Court decided that the Northern Irish Police Service's practice of indefinitely retaining the DNA profiles, fingerprints and photographs of suspected or convicted criminals constituted 'a disproportionate interference with the applicant's right to respect for private life' ${ }^{85}$ A post-Brexit agreement on intensive judicial cooperation in criminal matters that denies a strong role to an independent court might amount to nothing but unorganised case-by-case cooperation of the sort that the EU conducts with other third countries.

\section{THE PROBLEM OF FISHING ZONES}

Fishing zones became a top issue in the negotiations - the last of three red lines drawn by the UK delegation (besides the rejection of any role for the ECJ, and total British independence in law-making). As a red line, this is totally out of proportion for a sector with no more than 100,000 employees in the entire EU27, and only 7,300 in the UK, contributing much less than 1 per cent of the

83 Ibid, Sections 27-53.

84 Statement of Michel Barnier on Brexit negotiations, 5 March 2020: 'the UK has informed us that it will not formally commit to continue applying the European Convention on Human Rights. Nor does it want the European Court of Justice to play its proper role in interpreting European law - this is particularly serious when it comes to the fundamental rights of individuals', available at https://ec.europa.eu/commission/ presscorner/detail/de/speech_20_402, last accessed 24 September 2020.

85 European Court of Human Rights, Judgment of 13 February 2020, no. 45245/15, $E$ Gaughran $v$ the United Kingdom; compare Bodson, 'Judicial Partners Forever? Two Challenges Preventing a Fast and Effective Future Judicial Cooperation, in Aktoudianakis/Zuleeg/Wachowiak, Towards an Ambitious, Broad, Deep and Flexible EU-UK Partnership? European Policy Centre, 2020, pp.97-103, esp. footnote 11. 
respective region's GDP. ${ }^{86}$ In the EU, only a small number of all fishermen (and of employees of fishing industries) are affected at all, mainly in the Netherlands, Denmark, Spain and France. Yet the issue is politically and symbolically charged. The Queen's Speech in 2017 announced that Brexit 'will allow [the UK] to control access to [its] territorial waters'. ${ }^{87}$ While the UK insists on its territorial rights, the EU wants the regime to remain unchanged. Fishermen in the UK are among the fiercest Brexiteers, because the decline of UK fisheries went hand in hand with the allotment of fishing rights to fishermen in the rest of the EU, who now account for 60 per cent of the catch in British waters (of which three quarters are marketed on the continent). The British claim is now that 'British fishing grounds are first and foremost for British boats'. ${ }^{88}$

Britain does not automatically have the upper hand in this matter: it must fret about EU restrictions on imports of British fish, which in turn would badly hit the British fisheries sector. The UK therefore insists on free trade in fish after Brexit. Some observers fear that the fisheries issue, which on the British side is fuelled by activist fishermen and public opinion, could cause the failure of the negotiations, despite the modest magnitude of the problem. However, it symbolises the intricacies of the post-Brexit negotiations, of whose failure it would be the focal point rather than the decisive cause.

\section{SUMMARY AND CONCLUSIONS}

In this chapter we have reviewed the main economic and legal problems of Brexit.

The economic literature agrees that Brexit entails an economic loss for both the UK and the EU, but more so for the former, whose GDP is likely to incur a one-time 5-7 per cent drop (not counting the coronavirus effect). These

86 European Commission, Employment in the Fisheries (2017), available at https:// ec.europa.eu/fisheries/3-employment_en, last accessed 24 September 2020.

87 The Queen's Speech and associated background briefing, on the occasion of the opening of Parliament, 21 June 2017, available at https://assets.publishing.service.gov .uk/government/uploads/system/uploads/attachment_data/file/620838/Queens_speech 2017_background_notes.pdf, last accessed 24 September 2020; Le Gaillic/Mardle/ Metz, 'Brexit and Fisheries: A Question of Conflicting Expectations', 2018, available at https://onlinelibrary.wiley.com/doi/full/10.1111/1746-692X.12200, last accessed 24 September 2020.

88 Langhammer, 'Fischerei darf nicht zum Stolperstein der Brexit-Verhandlungen werden' ['Fisheries must not become a stumbling block of Brexit negotiations'], Kiel Institute for the World Economy, Kiel Focus, 2020, available at www.ifw-kiel .de/de/publikationen/kiel-focus/2020/fischerei-darf-nicht-zum-stolperstein-der-brexit -verhandlungen-werden-0/, last accessed 24 September 2020. 
economic losses would be part of the price the UK would have to pay for the restoration of its full sovereignty in matters of international trade in the event of a hard Brexit. Ejan Mackaay depicts in this volume the extent to which this trade-off between autonomy and wealth has been catalysed by populism. That the present British government even denies the existence of a trade-off must be heavily criticised.

The UK owes much of its prosperity to its membership in the EU. However, with the Union's sturdiness and doctrinal inflexibility in decision-making, and the strain this puts on social welfare institutions such as the National Health Service, the Union may have put off a fair number of Britons whose support could have effected a Europe-friendlier outcome of the Brexit referendum. While the free movement of persons as such is certainly a non-negotiable European asset, more flexibility in handling it in the face of mass migration might have removed at least some of the grist from the Brexiteers' mills.

When the die was cast and it was clear that the UK would withdraw from the EU, the campaigners for 'taking back control' started targeting the European Court of Justice. When the UK entered the EU in 1973, it cannot have been unaware of the ECJ being an atypical court and a motor of European integration, but its increasing uneasiness with the ECJ accumulating 'super-constitutional' powers is also understandable. That the UK government now declares any form of ECJ involvement in the future legal relations with the Union a 'red line' (a line that is also extended to the ECHR in police and judicial matters) is out of proportion but may indeed hinder substantial agreement on important issues.

Many observers on the continent had believed that Britain would accept the option of remaining with one foot in the single market, with the free movement of persons waived, and referred to this as cherry-picking. It soon turned out that this was a misapprehension of what was, or what became, the British position - for the cherries cannot be picked without their stems, twigs and even branches, namely ECJ jurisdiction, and common standards on matters such as environment, labour, social policy, health and safety, animal welfare and others. The blurry concept of 'leaving the EU' has since yielded to 'taking back control' and even the vision of a 'Singapore on Thames'. But whatever many Brexiteers may believe, the UK will not walk out of the EU strengthened and boldened, but rather unprotected by what it claims to match the interests of a sovereign country more than anything else: WTO law. Given the dysfunctional WTO dispute settlement mechanism, the UK will have to dodge and to strive for preferential trade agreements, which are yet to be concluded (which will take not months but years). As regards the future of EU-UK trade relations, both sides have not even agreed on a common denominator so far, and the odds of failing to achieve even a trade agreement in 2020 are high. The EU frets about perturbation from a UK that is reluctant to observe all legal 
or economic standards, but Europe may take comfort in the expectation that any trade imbalance an 'unleashed' Britain may inflict upon it will likely be mitigated by adjustments in the exchange rate sooner or later.

The UK 'taking back control' does not mean turning its back on the EU, to which it keenly wishes to continue providing financial services, with 'passporting' being its primary goal. This goal defies its own precept, which is to eschew European integration - because passporting is nothing but an implementation of the freedom to provide services. How participation in the EU's single financial market shall work while rejecting all EU law and ECJ involvement is an open question. The British desire for 'passports' understandably triggered unfriendly remarks: banking profits shall accrue to London, but in the next financial crisis the losses shall be covered by Brussels. However, since the EU has also profited from the expertise of the British financial sector and supervision, it is in the interest of both sides that British financial services not be pushed back from the continent and that a pragmatic solution be found soon.

While one may be pessimistic about the success of the EU-UK negotiations before the end of the transition period in December 2020, the long-term perspectives for an agreement are less dire. The common features - democracy and the market economy; the importance of private autonomy - outweigh the dividing ones. Economic scholars agree on geography as a particularly important feature. Britain is geographically so close to continental Europe that forces of economic gravity make close and comprehensive future economic cooperation and integration very likely. Sooner or later, politicians will be drawn back to the negotiating table. 